\title{
A Day That Changed Lives
}

Donald F. Weaver, MD, PhD, FRCPC

Neurology ${ }^{\circledR} 2021 ; 96: 583-585$. doi:10.1212/WNL.0000000000011547

Correspondence

Dr. Weaver

donald.weaver@

uhnresearch.ca
Sighing with dejection, I rolled towards the window adjacent to my bed and stared into the sullen, rainy October night—another 4:00 AM early morning awakening. This pattern had been ongoing for weeks and was becoming exhausting. For the next 2 hours I restlessly tossed, suffering random thoughts, obscured by fatigue and darkness; I cannot fully describe the disquiet inflicted upon me by these hours of unrest. Finally, at 6:00 AM, the clock-radio alarm fulfilled its unnecessary duty, heralding the start of yet another day. This morning's Classic FM "arousing music to awaken" was "Jupiter" from The Planets orchestral suite by Holst. Try as I might, I could not feel inspired. I paused, staring at myself in the mirror. I looked tired and demoralized. I sighed again, and prepared for the day ahead.

After breakfast, I ventured outside for the 3-block walk to the subway station. The sun seemed disinclined to undertake its obligation to ascend the morning sky-the day was dreary and melancholic. I took a deep breath of air, heavy with the recent rain yet still impregnated with the reek of urban life. I boarded the transit train and endured the ever-changing monotony of my co-commuters' bored faces as we lurched along. As always, I eventually arrived at the hospital. I headed to the outpatient clinic.

The first patients of the day were not an optimal start. One was a big man, with a big face and an emphatic nose flared at the nostrils in preparation for disagreement, and disagreeable he was. He became furious at me for advising that I intended to report him for suspension of his driver's license "just because he might have early dementia." He had been driving for many years and no neurologist was going to stop him. I explained to him (and his family) my societal duties; he yelled, slammed the door, and left, exclaiming that I had just ruined his life. The next patient was somewhat better-an entertaining man with an intriguing moustache through which he had clearly strained breakfast. We laughed, I adjusted his medications, he left happy (I think). I continued to cycle patients through my examination rooms in my well-disciplined but rather rigid and always regrettably rushed fashion.

Then, unexpectedly, my regimented, machine-like efficiency was interrupted when a medical student, Imindu Liyanage, asked if he could observe my clinic. At the large teaching hospital at which I work, clinician-researchers are not normally assigned medical students in the outpatient clinics, with this task being preferentially assigned to clinician-educators. However, this student, being interested in research and dementia, had actually sought me out specifically; he was eager and curious, so I welcomed him and suggested we see some patients together. We conjointly assessed a 53-year old woman with early onset rapidly progressing Alzheimer's and an 83-year old woman with a slowly evolving dementia, probably Alzheimer's. Both of these women had progressive memory and cognitive problems, but my suggestion of an Alzheimer's diagnosis was the first time anyone had used the dreaded "A word" to them or their families-multiple lives had just been changed.

Normally on clinic days I work through lunch. Today, however, there was a "no-show" and an unexpected cancellation, unlucky for my billing quota but lucky for Imindu, who was now going to have lunch. I bought him a cafeteria sandwich and we went to my office to talk about medicine, neurology, and life. I expounded platitudes about the brain being "what makes us, us" and the "ultimate frontier." As we chatted, I appreciated his idealism, principles, energy, and enthusiasm, and then it dawned on me-I wanted these qualities back. I realized he was me, 30 
years ago. I reflected and recognized that Imindu was in fact a different type of mirror, an animated one that enabled me to see myself from years gone by-an image I liked.

On the notice board in my office, I have a yellowed piece of paper pinned to the top of the board, obscured by administrative notices:

"To care, to cure, disease of brain

With scientific hand humane"

Imindu read it aloud. "Inspiring," he declared.

I replied, "It's from a poem I wrote many years ago. I had forgotten it-in more ways than one. Maybe I should read the entire poem again, or even publish it.”

"Well, I rather like it, and yes, you should," he responded. "And I do find your clinic interesting, sir."

Our conversation was abruptly ended by a message informing us that multiple patients had arrived. We returned to clinic.

The afternoon afforded some wonderful experiences and interactions with the people attending the clinic. Since Imindu would be evaluating several patients, I had extra time to lavish on others, answering all questions in detail. One family in particular appreciated this extra time. A woman with mild dementia arrived with her 2 daughters. Apparently 30-35 years earlier, this woman had been "knocked senseless" multiple times and battered many more times by a physically abusive husband. I had a long, thoughtful conversation with the patient and her family, and we discussed if repetitive head trauma from domestic violence was a risk factor for $\mathrm{Alz}$ heimer's disease. They fell silent, never having considered this before. They left visibly shaken, with one daughter commenting, "After all these years, his abuse keeps abusing."

Other families likewise appreciated the extra time, interest, and compassion-consoling and caring for people suffering incurable disease of brain. I felt satisfied; this is why I was doing medicine.

Meanwhile, Imindu completed 2 new assessments. The first was a man with probable Alzheimer's and a long history of chronic gingivitis. Although impossible to ascertain if this was coincidental or correlated, it did lead to a spirited discussion about oral bacteria as a possible dementia risk factor, as well as not-so-new infection theories of Alzheimer's.

Our final assessment was another person with dementia. During mental status testing, Imindu noticed that this person could draw a rectangular cube but not a square cube. Imindu challenged me to provide an explanation for this observation. I failed him. There being no more people to assess, I gave Imindu one further problem to ponder: "Consider the people you have seen today. Is Alzheimer's just one disease, or is it multiple diseases that we are currently unable to differentiate?" He looked pensive, but up to the challenge.

Continuing, I said, "And before you depart, my final lesson of the day. When you study human health, do so both intellectually and aesthetically; when you help people who are unwell use both science and humanism-never stop thinking dispassionately, never stop caring compassionately.”

"I learned a lot from you," said Imindu before departing.

"And I learned a lot from you, too," I replied. He seemed genuinely surprised, but pleased that I had offered this response.

And thus the clinic ended, and I was sincerely sorry that it had. The luxury of this intellectual stimulation had eradicated the remnants of my melancholia. I made a personal resolution: namely, to return to my motivations and principles of 4 decades ago. I was there to help people, to understand disease, and to celebrate the beauty of medical science.

Before leaving the hospital, I spoke with the clinic booking secretary and despite her protestations about jeopardizing my capacity to reach my billing threshold, I requested greater time allocations for patient assessments. Sometimes priorities have to be adjusted. Today had started a process of change for me. Later, as I walked homeward from the subway station, the weather had become fine, the sky cloudless. My senses were gratified and refreshed by the smell of freshly fallen wet autumn leaves.

That evening, I did something which I had not done in a long time-responding to my need for nostalgia, I watched one of my old recordings of the 1970s' The Ascent of Man television series by Jacob Bronowski (the mathematician-turned-poetturned-humanist popularizer of science). Dated though this series may be, its message remains timeless and compelling: science is a very human form of knowledge, integral to our culture and central to human progress.

This realization of the humaneness of science had been one of the key factors contributing to my decision to pursue medicine. As an enthusiastic, idealistic teenager struggling with the decision of pursuing either mathematics or medicine, I had watched The Ascent of Man. Bronowski had resolved the dilemma for me: science is an essential but very human activity, which we must embrace both passionately and compassionately in order to touch the lives of people. Almost 50 years ago, I had vowed to live by this dictum through the study of medicine. Today I had rediscovered that vow. Like a wedding anniversary, I had needed to renew my vows, to reaffirm my commitment. Today had reminded me about why I was practicing medicine. I embraced this reaffirmation, sensing the possibility that all was going to be right in my world again and believing that my recent feelings of diminished motivation could be overcome-feelings which I suspect many of my 
colleagues have faced in past (usually in silence) and many others will experience in future.

Later that day, as I climbed into bed, my thoughts, now more contented and optimistic, were eventually lost in the darkness and the distance of the night horizon; all was quiet apart from agitated leaves falling from the trees. Over the coming weeks, I changed professionally and personally, with my rediscovered passion for medicine enabling a greater sense of purpose and happiness. My sighs became those of contentment, and at times even delight. 


\title{
Neurology
}

\author{
A Day That Changed Lives \\ Donald F. Weaver
}

Neurology 2021;96;583-585 Published Online before print January 27, 2021

DOI 10.1212/WNL.0000000000011547

This information is current as of January 27, 2021

\section{Updated Information \& Services}

\section{Subspecialty Collections}

\section{Permissions \& Licensing}

\section{Reprints}

including high resolution figures, can be found at: http://n.neurology.org/content/96/12/583.full

This article, along with others on similar topics, appears in the following collection(s):

\section{All Cognitive Disorders/Dementia}

http://n.neurology.org/cgi/collection/all_cognitive_disorders_dementia Alzheimer's disease

http://n.neurology.org/cgi/collection/alzheimers_disease

\section{Cognitive aging}

http://n.neurology.org/cgi/collection/cognitive_aging

Cognitive neuropsychology in dementia

http://n.neurology.org/cgi/collection/cognitive_neuropsychology_in_de mentia

Frontotemporal dementia

http://n.neurology.org/cgi/collection/frontotemporal_dementia

Information about reproducing this article in parts (figures,tables) or in its entirety can be found online at:

http://www.neurology.org/about/about_the_journal\#permissions

Information about ordering reprints can be found online:

http://n.neurology.org/subscribers/advertise

Neurology ${ }^{\circledR}$ is the official journal of the American Academy of Neurology. Published continuously since 1951, it is now a weekly with 48 issues per year. Copyright () 2021 American Academy of Neurology. All rights reserved. Print ISSN: 0028-3878. Online ISSN: 1526-632X.

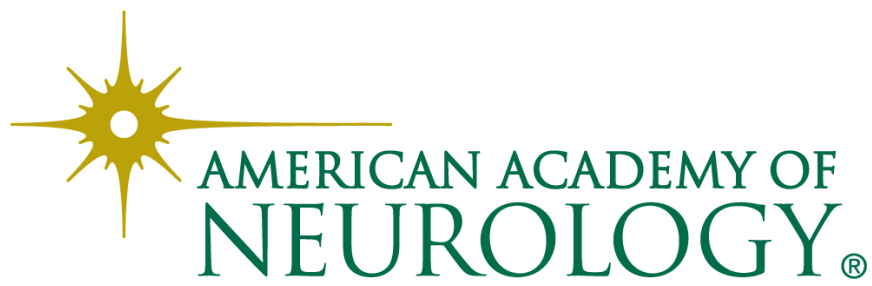

